\title{
GAMBARAN TINGKAT PENGETAHUAN SISWA SEKOLAH MENENGAH PERTAMA MENGENAI DIARE DI WILAYAH KERJA UPT KESMAS BLAHBATUH II, KABUPATEN GIANYAR BALI TAHUN 2015
}

\author{
Nyoman Bendhesa Wirananggala \\ Program Studi Pendidikan Dokter, Fakultas Kedokteran Universitas Udayana
}

bendhesa@gmail.com

ABSTRAK

Diare masih berpotensi sebagai masalah kesehatan masyarakat di Indonesia. Diare menjadi sepuluh penyakit terbanyak di UPT Kesmas Blahbatuh dari tahun 2012-2014. Pada tahun 2013 terdapat 1017 kasus diare akut yang tercatat, sedangkan pada tahun 2014 terdapat 604 kasus diare akut. Pada tahun 2012, 40,3\% dari seluruh kasus diare akut terjadi pada kelompok umur 5-14 tahun dan pada tahun 2014 57,8\% kasus diare terjadi pada kelompok umur 5-14 tahun. Dalam upaya mengantisipasi masalah ini, UPT Kesmas Blahbatuh II melaksanakan berbagai kegiatan yang tercakup dalam program Kesehatan Lingkungan dan Program Promosi Kesehatan Masyarakat (PKM). Tetapi kerjasama lintas program di lapangan belum optimal terutama dengan PKM. Untuk mengembangkan program PKM yang lebih efektif, penelitian ini mengkaji sejauh mana siswa SMP di wilayah kerja UPT Kesmas Blahbatuh II memahami tentang diare dan bagaimana penanganannya. Penelitian ini bertujuan untuk mengetahui gambaran tingkat pengetahuan siswa sekolah menengah pertama tentang diare di wilayah kerja UPT Kesmas Blahbatuh II. Penelitian ini dilakukan pada bulan MaretApril 2015 dengan menggunakan rancangan cross sectional deskriptif. Data diperoleh dari wawancara berstruktur dengan kuisioner. Responden penelitian adalah 46 siswa di wilayahkerja UPT Kesmas Blahbatuh II yang dipilih secara systematic random sampling. Data yang diperoleh dianalisis menggunakan program SPSS 22.0 dan disajikan dalam bentuk tabel dan naratif. Berdasarkan analisis dan pembahasan dapat disimpulkan,yaitu tingkat pengetahuan sangat kurang (58,7\%), tingkat pengetahuan kurang $(41,3 \%)$ dan tingkat pengetahuan baik $0 \%$.

Kata kunci: Tingkat Pengetahuan, Diare, Siswa SMP, UPT Kesmas Blahbatuh II

\section{OVERVIEW OF KNOWLEDGE LEVEL OF JUNIOR HIGH SCHOOL STUDENTS ABOUT DIARRHEA IN THE WORKING AREA OF BLAHBATUH II PUBLIC HEALTH UNIT, GIANYAR BALI 2015}

\section{ABSTRACT}

Diarrhea is still potential to develop as a public health problem in Indonesia. Diarrhea becomes top ten diseases in Blahbatuh Public Health Unit from 2012-2014. In 2013 there were 1017 cases of acute diarrhea were recorded, while in 2014 there were 604 cases of acute diarrhea. In $2012,40.3 \%$ of all cases of acute diarrhea occur in the age group 5-14 years and in $201457.8 \%$ of cases of diarrhea occur in the age group of 5-14 years. In order to anticipate this problem, the Public Health Unit Blahbatuh II implementing various activities included in the program Environmental Health and Public Health Promotion Program (PKM). But cross-program cooperation in the field is not optimal, especially with PKM. PKM program to develop a more effective, this study examines the extent to which the junior high school students in the region of Blahbatuh Public Health Unit II understand about diarrhea and how to handle. This study aims to describe the level of junior high school students' knowledge of diarrhea in the region of Blahbatuh Public Health Unit II. This research was conducted in March-April 2015 by using descriptive cross sectional design. Data obtained from interviews with a structured questionnaire. Respondents are 46 students in the working area of 
Public Health Unit Blahbatuh II selected by systematic random sampling. Data were analyzed using SPSS 22.0 and presented in tabular form and narrative. Based on the analysis and discussion can be concluded, that the level of knowledge is very less (58.7\%), lack of knowledge level (41.3\%) and a good knowledge level of $0 \%$

Keywords: Knowledge level, Diarrhea, Junior High School Students, Blahbatuh Public Health II

\section{PENDAHULUAN}

Diare akut yang sampai saat ini masih menjadi masalah kesehatan baik di negara berkembang maupun di negara maju. Di Indonesia, kejadian sakit diare akut cenderung masih tetap dominan, terutama berdasarkan karakteristik penduduk, kelompok umur balitaadalah kelompok yang paling tinggi menderita diare. Riset Kesehatan Dasar tahun 2013 menunjukan angka insiden diare akut pada kelompok umur balita sekitar 5,1-6,7 episode/orang/tahun sedangkan pada kelompok umur 5-14 tahun 2,0-3,0 episode/orang/tahun. Tingginya kejadian diare perlu diantisipasi dengan melakukan peningkatan efektivitas pelayanan kesehatan dasar di Puskesmas dan Kerjasama lintas program serta lintas sektor. ${ }^{1}$

Diare masih menjadi masalah kesehatan yang memerlukan perhatian khusus di wilayah kerja UPT Kesmas Blahbatuh II. Diare akut tiap tahunnya dilaporkan dari puskesmas ini menjadi 10 penyakit terbanyak. Pada tahun 2013 terdapat 1017 kasus diare akut yang tercatat, sedangkan pada tahun 2014 terdapat 604 kasus diare akut yang tercatat di wilayah UPT Kesmas Blahbatuh II. ${ }^{1,2}$

Pada keempat desa wilayah kerja Puskesmas Blahbatuh II, dari tahun 2012 sampai dengan tahun 2014 memiliki pola penyebaran kasus diare akut yang sama berdasarkan kelompok umur dengan jumlah kasus terbanyak terjadi pada kelompok umur 5-14 tahun.

Gambaran ini menunjukkan bahwa pelaksanaan kerjasama lintas program dalam pencegahan diare di wilayah UPT Kesmas Blahbatuh II belum berjalan efektif dan menunjukan hasil yang optimal. Oleh karena itu, penelitian ini akan mengkaji sejauh mana tingkat pengetahuan kelompok usia sekolah khususnya siswa Sekolah Menengah Pertama (SMP) di wilayah UPT Kesmas Blahbatuh II tentang penyakit diare dan bagaimana penanganan dini diare yang dapat dilakukan di rumah. Semua pertanyaan tersebut di atas akan dijadikan dasar permasalahan untuk melakukan penelitian ini. ${ }^{3}$

\section{METODE PENELITIAN}

Penelitian dilakukan di seluruh Sekolah Menengah Pertama, Kecamatan Blahbatuh, Kabupaten Gianyar, pada bulan Mei 2015. Penelitian ini menggunakan rancangan penelitian deskriptif kuantitatif dengan pendekatan cross sectional. Populasi penelitian ini adalah semua siswa Sekolah Menengah Pertama yang terdaftar di SMP negeri dan swasta, di wilayah kerja UPT Kesmas Blahbatuh II, Kecamatan Blahbatuh, Kabupaten Gianyar. Sampel dalam penelitian ini adalah siswa yang merupakan bagian dari populasi yang telah dipilih secara acak. Terdapat kriteria inklusi yang harus dipenuhi untuk menjadi sampel diantaranya siswa tersebut merupakan siswa yang terdaftar di SMP negeri atau swasta di wilayah kerja UPT Kesmas Blahbatuh II, Kecamatan Blahbatuh, Kabupaten Gianyar. Terdapat pula kriteria ekslusi yaitu siswa yang menolak untuk dijadikan sampel dan siswa yang tidak hadir di sekolah saat pengumpulan data dilaksanakan. Dengan persyaratan sebagai berikut :

\section{Kriteria Inklusi :}

Siswa yang terdaftar di SMP negeri atau swasta di wilayah kerja UPT Kesmas Blahbatuh II, Kecamatan Blahbatuh, Kabupaten Gianyar

2. Kriteria Eksklusi :

a. Siswa yang menolak berpartisipasi

b. Siswa yang tidak hadir di sekolah saat pengumpulan data dilaksanakan.

Sampel dalam penelitian ini dipilih melalui teknik systematic random sampling. Pemilihan sampel diawali dengan pengelompokan berdasarkan Sekolah Menengah Pertama yang berada di wilayah UPT Kesmas Blahbauh II yaitu SMPN 1 Blahbatuh, SMP Blahbatuh dan SMP Tri Mandala. Terdapat tiga tingkat kelas di masing-masing SMP tersebut yaitu kelas VII (tujuh), VIII (delapan) dan IX (Sembilan). Dari ketiga tingkat kelas yang ada, siswa kelas IX tidak dapat dijadikan sampel karena sedang mengikuti persiapan Ujian Nasional dari sekolah 
masing-masing, sedangkan siswa kelas VII sudah kami jaidikan sampel survey awal untuk mengetahui gambaran pengetahuan siswa SMP dalam proses pembuatan proposal penelitian sehingga hanya tersedia siswa kelas VIII dari masing-masing sekolah yang dapat dijadikan sampel penelitian atau accidental sampling. Kemudianseluruh siswa kelas VIII dari ketiga SMP tersebut diurutkan dan diberikan nomor urut dipilih dengan teknik systematic random sampling.

Tabel 1. Kareteristik Umum Responden

\begin{tabular}{|c|c|c|c|c|}
\hline \multicolumn{2}{|c|}{ No. } & Karakteristik & Frekuensi & Presentase \\
\hline \multirow[t]{3}{*}{1} & Umur & - 13 & 11 & 23,9 \\
\hline & & - 14 & 32 & 69,6 \\
\hline & & - 15 & 3 & 6,5 \\
\hline \multirow[t]{3}{*}{2} & Sekolah & - SMP N 1 Blahbatuh & 20 & 43,5 \\
\hline & & - SMP Blahbatuh & 24 & 52,2 \\
\hline & & - SMP Tri Mandala & 2 & 4,3 \\
\hline \multirow[t]{2}{*}{3} & Penyuluhan & - $\mathrm{Ya}$ & 16 & 34,8 \\
\hline & & - Tidak & 30 & 65,2 \\
\hline \multirow[t]{4}{*}{4} & Waktu & - Tidak Pernah & 30 & 65,2 \\
\hline & Penyluhan & - <1 Bulan & 3 & 6,5 \\
\hline & & - 1-3 Bulan & 5 & 10,9 \\
\hline & & - >3 Bulan & 8 & 17,4 \\
\hline \multirow[t]{5}{*}{5} & Pemberi & - Tidak Pernah & 30 & 65,2 \\
\hline & Penyuluhan & - Tenaga Kesehatan & 8 & 17,4 \\
\hline & & - Kader Kesehatan & 6 & 13 \\
\hline & & - Tokoh Masyarakat & 2 & 4,3 \\
\hline & & - Lainnya & 0 & 0 \\
\hline
\end{tabular}

\section{HASIL PENELITIAN}

Penelitian ini dilakukan terhadap 46 siswa SMP dan semuanya bisa tercakup dalam penelitian. Karakteristik umum penelitian dapat dilihat pada table 1.

Tingkat pengetahuan siswa diperoleh dari hasil wawancara dengan menanyakan pengetahuan tentang definisi diare, bahaya diare, penyebab diare, penceghan diare, penanganan dini diare, pembuatan larutan oralit

dan perujukan penderita diare ke dokter. Dari data yang diperoleh kemudian dilakukan recoding scoring setelah data entry selesai dilakukan, dimana untuk masing-masing variabel diberi nilai 1 jika tahu dan 0 "nol" jika tidak tahu. Kemudian nilai dijumlahkan dan di-recode, jika jumlah 0 "nol" menunjukan pengetahuan siswa sangat kurang, jumlah nilai 1-4 menunjukan pengetahuan siswa kurang dan jika jumlah nilai 5-7 menunjukan pengetahuan siswa yang baik. Pengetahuan siswa mengenai ketujuh hal di atas menjadi penting dalam upaya pencegahan dan penanganan

diare.

Tingkat pengetahuan siswa diperoleh melalui wawancara dengan menanyakan pengetahuan tentang batasan diare, bahaya diare, penyebab diare, pencegahan diare, penanganan diare, pembuatan larutan oralit dan perujukan penderita diare ke dokter, puskesmas atau rumah sakit. Pengetahuan siswa mengenai semua hal tersebut menjadi penting untuk mengetahui tingkat pengetahuan siswa mengenai diare dalam definisi diare, pencegahan dan penanganan diare yang berimplikasi terhadap sikap dan perilaku siswa berkaitan dengan diare. Sesuai dengan pendapat Notoatmodjo, menyatakan bahwa pengetahuan berhubungan dengan perubahan sikap dan perilaku seseorang. Seseorang baru dapat mengubah sikap 
dan perilakunya untuk hidup sehat setelah memiliki pengetahuan yang baik tentang kesehatan. Begitu pula halnya dalam perilaku pencegahan dan penanganan diare. ${ }^{4}$

Tingkat pengetahuan siswa pada masing-masing aspek yang berkaitan dengan diareyaitu batasan diare, bahaya diare, penyebab diare, pencegahan diare, penanganan dini diare, pembuatan larutan oralit dan perujukan penderita diaredidapatkan melalui wawancara dengan menanyakan pengetahuan siswa tentang masing-masing hal yang terkait dengan masing-masing aspek diare. Dari data yang diperoleh untuk masing-masing aspek kemudian dilakukan scoring dengan nilai 1 jika tahu dan nilai 2 jika tidak tahu untuk masing-masing aspeknya. Kemudian dilakukan recoding, nilai 1 menunjukan tingkat pengetahuan baik dan nilai 2 menunjukan tingkat pengetahuan kurang.

Tabel 2. Tingkat Pengetahuan Diare Secara Umum

\begin{tabular}{|c|c|c|c|c|}
\hline No. & & Karakteristik & Frekuensi & Presentase \\
\hline \multirow[t]{3}{*}{1.} & Pengetahuan & Sangat Kurang & 27 & 58,7 \\
\hline & & Kurang & 19 & 41,3 \\
\hline & & Baik & 0 & 0 \\
\hline
\end{tabular}

\section{PEMBAHASAN}

Hasil yang didapatkan dapat dilihat pada

tabel 3 dimana tabel tersebut menunjukan tingkat pengetahuan sampel tentang batasan diare yang masih rendah, 91,3\% dari total sampel memiliki tingkat pengetahuan yang masih rendah mengenai batasan diare.

Tabel 3. Tingkat pengetahuan berdasarkan Masing-Masing Aspek

\begin{tabular}{llrrrc}
\hline No. & \multicolumn{1}{c}{ Variabel } & \multicolumn{3}{c}{ Tingkat Pengetahuan } \\
& & \multicolumn{2}{c}{ Baik } & \multicolumn{2}{c}{ Kurang } \\
\cline { 3 - 6 } & & f & \% & f & \% \\
$\mathbf{1}$ & Batasan Diare & 4 & 8,7 & 42 & 91,3 \\
$\mathbf{2}$ & Bahaya Diare & 4 & 8,7 & 42 & 91,3 \\
$\mathbf{3}$ & Penyebab Diare & 8 & 17,4 & 38 & 82,6 \\
$\mathbf{4}$ & Pencegahan Diare & 10 & 21,7 & 36 & 78,3 \\
$\mathbf{5}$ & Penanganan Dini Diare & 5 & 10,9 & 41 & 89,1 \\
$\mathbf{6}$ & Pembuatan Oralit & 4 & 8,7 & 42 & 91,3 \\
$\mathbf{7}$ & Perujukan Penderita Diare & 2 & 4,3 & 44 & 95,7 \\
\hline
\end{tabular}

Tingkat pengetahuan sampel tentang bahaya diare juga masih rendah dengan $91,3 \%$ dari total sampel memiliki tingkat pengetahuan yang kurang. Tingkat pengetahuan sampel tentang penyebab diare juga masih rendah, dari grafik di atas menunjukan $82,6 \%$ sampel dengan tingkat pengetahuan tentang penyebab diare yang kurang. Tingkat pengetahuan sampel tentang pencegahan diare juga masih rendah, dengan $78,3 \%$ sampel dengan tingkat pengetahuan kurang tentang pencegahan diare. Tingkat pengetauhan sampel tentang penanganan dini diare pun masih rendah, dengan $89,1 \%$ sampel dengan tingkat pengetahuan kurang tentang penanganan dini diare.
Kemudian untuk tingkat pengetahuan pembuatan larutan oralit, berdasarkan grafik di atas 91,3\% sampel memiliki tingkat pengetahuan yang kurang tentang pembuatan larutan oralit. Tingkat pengetahuan tentang waktu perujukan penderita diare juga masih rendah, dengan 95,7\% dari seluruh sampel memiliki tingkat pengetahuan kurang tentang perujukan penderita diare.

\section{SIMPULAN}

Berdasarkan hasil dan pembahasan maka dapat disimpulkan gambaran tingkat pengetahuan siswa SMP tentang diare di wilayah kerja UPT Kesmas Blahbatuh II ditemukan pada penelitian ditemukan 
sebesar $65,2 \%$ sampel belum pernah mendapatkan penyuluhan tentang diare baik dari tenaga kesehatan, kader kesehatan, tokoh masyarakat atau lainnya, ditemukan tingkat pengetahuan tentang diare secara umum yang masih rendah, dengan $58,7 \%$ sampel memiliki tingkat pengetahuan sangat kurang dan $41,3 \%$ dengan tingkat pengetahuan kurang tentang diare secara umum, tingkat pengetahuan tentang batasan diare yang masih kurang, dengan $91 \%$ sampel memiliki tingkat pengetahuan kurang tentang batasan diare, tentang bahaya diare yang masih kurang, dengan 91\% sampel memiliki tingkat pengetahuan kurang tentang bahaya diare, tingkat pengetahuan tentang penyebab diare yang masih kurang, dengan $83 \%$ sampel memiliki tingkat pengetahuan kurang tentang penyebab yang dapat menyebabkan terjadinya diare, pengetahuan tentang pencegahan diare yang masih kurang, dengan $78 \%$ sampel memiliki tingkat pengetahuan kurang tentang bagaimana cara pencegahan terjadinya diare, pengetahuan tentang penanganan dini diare yang masih kurang, dengan $89 \%$ sampel memiliki tingkat pengetahuan kurang tentang bagaimana penanganan dini diare yang dapat dilakukan di rumah, pengetahuan tentang cara pembuatan larutan oralit diare yang masih kurang, dengan $91 \%$ sampel memiliki tingkat pengetahuan kurang tentang bagaimana cara pembuatan larutan oralit di rumah, tingkat pengetahuan tentang perujukan penderita diare yang masih kurang, dengan $96 \%$ sampel memiliki tingkat pengetahuan kurang tentang kapan penderita diare harus dibawa ke dokter, puskesmas atau rumah sakit., ${ }^{5,6}$

\section{DAFTAR PUSTAKA}

1. Menteri Kesehatan Republik Indonesia. Laporan Riskesdas Nasional 2012. Badan Penelitian dan Pengembangan Kesehatan. Departemen Kesehatan RI. Hal. 75-77; 2013

2. Menteri Kesehatan Republik Indonesia. Laporan Hasil Riset Kesehatan Dasar (Riskesdas) Nasional 2013. Badan Penelitian dan Pengembangan Kesehatan. Departemen Kesehatan RI. Hal. 106109; 2014.

3. Green LW, Kreuter W. Health Promotion Planning An Educational and Environmental Approach. $2^{\text {nd }} \mathrm{Ed}$, London: Mayfield Publishing Company, hal 142-177; 1991.

4. Kasman. Faktor- Faktor Yang Berhubungan Dengan Kejadian Diare Pada Balita di Puskesmas Air Dingin Kecamatan Koto Tangah Kota Padang Sumatra Barat. Accessed 4 April, 2015. 2003

5. Muninjaya AAG. Manajemen Kesehatan. Volume I. Hal 13-14. Jakarta; EGC; 1999.

6. Notoatmodjo S. Ilmu Kesehatan Masyarakat .Jakarta: Rineka Cipta; 2003 